\title{
Analisis Besi dalam Ekosistem Lamun dan Hubungannya dengan Sifat Fisikokimia Perairan Pantai Kabupaten Donggala
}

\author{
Tahril(1*), Paulina Taba ${ }^{2)}$, Nursiah La Nafie ${ }^{2)}$, dan Alfian Noor ${ }^{2)}$ \\ 1)Program Studi Kimia, Fakultas Keguruan dan Ilmu Pendidikan, Universitas Tadulako, \\ Jalan Uwe Goda, Palu 94118 \\ 2)Jurusan Kimia, Fakultas Matematika dan Ilmu Pengetahuan Alam, Universitas Hasanuddin, \\ Jalan Perintis Kemerdekaan Km 10, Makassar 90245 \\ Diterima 03-08-2009 Disetujui 18-08-2010
}

\begin{abstract}
The objectives of the study are to describe the iron content of seagrass area ecosystem and its relation with nature of physico-chemical territorial water. The sampling of seagrass was conducted in purposive sampling technique for every status of the field and performed in three spots of the seagrass ecosystem region with reference to the depth of water and the current direction. Based on statistical tests of factorial and variance analysis indicate that the quality of physico-chemical territorial water in the coastal region of Donggala regency still very good, relatively. The result also showed, The Demand Oxygen and the turbidity gave a positive effect to Feseagrass improvement in its various association. Besides, the limiting factor for the low of Fe-seagrass is the height of salinity and water temperature. If the results were combined with another micro and macro mineral analysis will to become the basic for estimating the status of seagrass fertility.
\end{abstract}

Keywords: iron, physico-chemical, seagrass

\section{PENDAHULUAN}

Lamun merupakan salah satu ekosistem yang paling produktif, selain hutan mangrove dan terumbu karang pada perairan pesisir pantai. Secara ekologis, lamun dapat berperan sebagai stabilisator sedimen karena mampu melindungi terumbu karang dari sedimentasi dengan ciri khas akar rizomanya. Padang lamun juga dapat berperan sebagai filtrasi air serta pendukung utama kehidupan perikanan dan unggas air di pesisir pantai. Padang lamun mampu mengambil nutrient melalui daun serta sistem akarnya, dan pada umumnya di daerah tropis konsentrasi nutrient terlarut dalam air laut agak rendah (sering di bawah batas yang dapat dideteksi), sementara konsentrasi air poros dalam sedimen biasanya sangat tinggi. Pengambilan nutrient dari kolom air oleh daun lamun dapat dianggap tidak terlalu penting jika dibandingkan dengan pengambilan nutrien oleh akar dari sedimen (Short, 1987 dalam Persulessy et al., 1998). Meskipun demikian pengambilan nutrient oleh daun dari kolom air dan akar dari sedimen perlu dicermati secara ilmiah dengan logika berpikir yang kreatif. Nutrient sedimen berada dalam tiga bentuk yakni; terlarut dalam air poros sedimen, teradsorpsi pada permukaan sedimen dan

\footnotetext{
*Telp: +6285240342000

E-mail : tahrilbuhari@yahoo.co.id
}

terdapat pada struktur kisi butiran-butiran sedimen. Proses pengambilan nutrient oleh lamun melalui daun dan akar, menarik untuk dikaji secara mendalam terutama dalam hal bagaimana proses pengambilan nutrient berlangsung dari air atau sedimen yang mengandung logam runut esensial, termasuk besi (Fe).

Pertumbuhan, morfologi, kelimpahan dan produksi primer lamun pada suatu perairan umumnya ditentukan oleh ketersediaan zat hara fosfat, nitrat dan amonium yang berperanan penting dalam menentukan fungsi padang lamun (Erftemeijer, 1992; Patriquin, 1992; Yamamuro et al., 2003). Besarnya konsentrasi penyerapan fosfat oleh lamun tergantung dari jenis lamun dan panjang dan lebar daun (Saleh, 2003). Disamping itu, ketercukupan unsur hara mikro seperti besi, mangan, dan tembaga dalam ekosistem dapat menentukan faktor pertumbuhan tanaman lamun.

Besi merupakan unsur hara esensial (hara mikro) bagi pertumbuhan tanaman lamun. Besi merupakan bagian dari enzim tertentu dan protein yang berfungsi sebagai pembawa elektron pada fase terang fotosintesis dan respirasi (Lakitan, 2007). Sifat fisiologis yang dimiliki lamun dalam memanfaatkan zat-zat anorganik $\mathrm{H}_{2} \mathrm{O}$ dan $\mathrm{CO}_{2}$ oleh krolofil diubah menjadi zat organik (karbohidrat) dengan bantuan sinar matahari 
(fotosintesis) di dasar perairan merupakan hal yang sangat menarik dan perlu diteliti secara mendalam. Beberapa faktor yang berpengaruh dalam pembentukan klorifil, antara lain ketersediaan unsur besi (Taiz \& Zeiger, 2002; Silva \& Santos, 2003; Lakitan, 2007). Peran yang potensial bagi ekosistem padang lamun dalam perairan laut dangkal mengakumulasi logam dalam pertumbuhannya, dapat dijadikan indikator peningkatan kadar logam, khususnya logam besi.

Gangguan dan perubahan secara fisik pada suatu variabel lingkungan seperti suhu, salinitas, kecerahan dan secara kimia seperti ketersedian unsur hara dalam lingkungan perairan akan mengakibatkan perubahan komposisi spesies dari komunitas lamun. Perubahan komunitas lamun seperti itu dapat dimanfaatkan untuk memonitor keadaan lingkungan pada saat tersebut dan juga dapat digunakan untuk menduga hubungannya dengan kondisi lingkungan di masa selanjutnya. Penelitian ini dimaksudkan untuk mengatahui hubungan konsentrasi besi dalam tumbuhan lamun terhadap variabel-variabel fisikokimia perairan agar dapat digunakan secara periodik untuk menduga tekanantekanan yang terjadi pada suatu lingkungan ekosistem padang lamun.

\section{BAHAN DAN METODE}

Lokasi dan Waktu Penelitian. Penelitian ini dilakukan di perairan pantai Kabupaten Donggala Provinsi Sulawesi Tengah. Penelitian dilakukan selama tiga bulan (September, Oktober, dan Nopember 2008). Analisis logam Fe dilakukan di laboratorium STORMA (Stability of Rainforest Margins in Indonesia) Fakultas Pertanian Universitas Tadulako dan Laboratorium Kimia Radiasi Fakultas Matematika dan IImu Pengetahuan Alam Universitas Hasanuddin.

Pengambilan Sampel. Pencuplikan lamun (spesies Enhalus acorodies) pada setiap status padang lamun dilakukan pada tiga titik dalam kawasan ekosistem padang lamun, dengan mempertimbangkan kedalaman perairan dan arah arus. Pembagian zonasi ini didasarkan pada zonasi dimana kedalaman yang masih memungkinkan ditembusi sinar matahari serta struktur kedalaman pesisir pantai Kabupaten Donggala Propinsi Sulawesi Tengah. Waktu pencuplikan lamun adalah keadaan pasang perbani lautan, peralihan antara pasang purnama pertama dan kedua pada saat arus pasang surut (pasut) lemah. Hal tersebut juga dikaitkan dengan proses naik-turunnya paras laut (sea level) secara berkala dan keadaan pasut harian lautan. Bersamaan dengan pengambilan sampel lamun, dilakukan pula pengukuran langsung sifat fisikokimia perairan.

Rancangan Perlakuan dan Analisis Data. Rancangan perlakuan dibuat untuk melihat hubungan konsentrasi $\mathrm{Fe}$ dalam tumbuhan lamun yang berasosiasi dengan sumberdaya perairan lainnya, yaitu mangorove, mangrove-terumbu karang, dan terumbu karang. Rancangan perlakuan yang digunakan merupakan kombinasi dua faktor, yaitu: $L=$ assosiasi; L1 = asosiasi lamun-mangrove, L2 = asosiasi lamunmangrove-terumbu karang, L3 = asosiasi lamunterumbu karang; dan $\mathrm{S}=$ status lamun (tutupan), $\mathrm{S} 1$ : ( $>60 \%$ = sangat padat), S2 : (39-59\% = padat), S3 : $(<39 \%=$ tidak padat). Dengan demikian diperoleh $2 x$ $3 \times 3$ ulangan $=27$ perlakuan. Hubungan antara parameter sifat fisikokimia perairan $(X)$ dengan konsentrasi $\mathrm{Fe}(\mathrm{Y})$ pada setiap kombinasi perlakuan dianalisis dengan sidik jalin. Untuk menguji perbedaan besarnya $P x_{1} y, P x_{2} y, P x_{3} y$, dan $P x_{4} y$, digunakan uji $F(a$ 0,05).

\section{Metode Kerja}

1. Pengambilan dan Preparasi Sampel. Sampel lamun diambil secara acak di wilayah pesisir Kabupaten Donggala Provinsi Sulawesi Tengah (Gambar 1) kemudian dicampur sehingga diperoleh hanya 1 sampel setiap titik amatan. Keseluruhan sampel yang diambil sebanyak 9 sampel setiap kelompok perlakuan, sehingga totalnya sebanyak 27 sampel (3 status ekosistem padang lamun $x 9$ obyek pengamatan). Bersamaan dengan pengambilan sampel lamun, dilakukan pula pengukuran sifat fisikokimia perairan.

Sampel lamun dicuci dengan akuades hingga benar-benar bersih, kemudian diangin-anginkan dan dipotong kecil-kecil, dimasukkan ke dalam wadah dan dikeringkan dengan oven selama \pm 3 hari pada suhu $70^{\circ} \mathrm{C}$. Sampel lamun yang telah kering digiling menggunakan alat penggiling (Retsch SM 2000 dan Retsch ZM 100) sehingga diperoleh sampel halus. Ditimbang sebanyak \pm 100 mgram dan dimasukkan ke dalam wadah PTFE (Poli Teknical Flue Etsilen) dan ditambahkan $2 \mathrm{ml} \mathrm{HNO}_{3}$ pekat, kemudian wadah PTFE ditutup rapat. Selanjutnya, dipanaskan dalam oven pada suhu $200^{\circ} \mathrm{C}$ selama $\pm 14 \mathrm{jam}$. Setelah larutan sampel dingin, larutan sampel difilter kedalam labu ukur $50 \mathrm{ml}$ dan diimpitkan dengan easypure hingga tanda tera, larutan sampel siap untuk diukur. 


\begin{tabular}{ccc}
\hline NO. & LON & LAT \\
\hline 01 & 119,868300 & 0,253450 \\
02 & 119,900867 & 0,220167 \\
03 & 119,900933 & 0,236283 \\
04 & 119,976833 & 0,481083 \\
05 & 119,978217 & 0,482967 \\
06 & 120,035983 & 0,581600 \\
07 & 119,898400 & 0,494000 \\
08 & 119,905967 & 0,493417 \\
09 & 119,976050 & 0,480867 \\
10 & 119,841583 & $-0,092950$ \\
11 & 119,820483 & $-0,114933$ \\
12 & 119,807500 & $-0,137233$ \\
13 & 119,845267 & $-0,085450$ \\
14 & 119,872100 & $-0,043850$ \\
15 & 119,883933 & $-0,014983$ \\
16 & 119,881783 & 0,100983 \\
17 & 119,864233 & 0,101700 \\
18 & 119,830750 & 0,142033 \\
19 & 119,760500 & 0,700000 \\
20 & 119,756217 & 0,701417 \\
21 & 119,782517 & 0,702500 \\
22 & 119,667367 & 0,708850 \\
23 & 119,691167 & 0,710833 \\
24 & 119,715733 & 0,713817 \\
25 & 119,658200 & 0,709900 \\
26 & 119,665833 & 0,710300 \\
\hline & 119,644200 & 0,710600 \\
\hline & $1, P e$ & \\
\hline 1
\end{tabular}
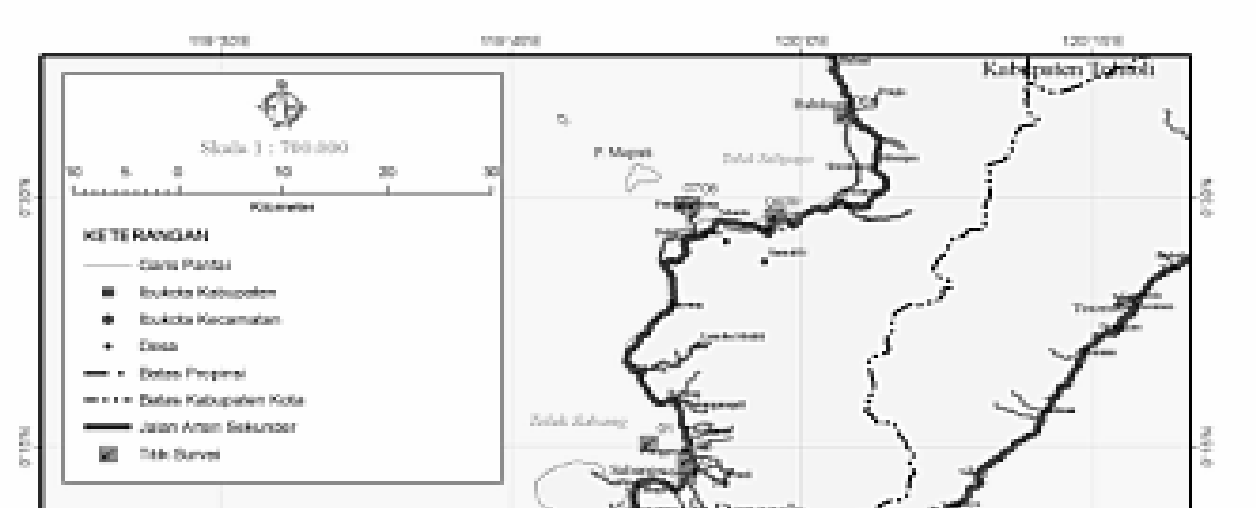

Gambar 1. Peta pengambilan sampel lamun di wilayah pesisir kabupaten donggala

2. Analisis dengan ICP-OES. Blanko, larutan baku standar, dan sampel lamun dianalisis dengan menggunakan peralatan ICP-OES (Inductively Coupled Plasma-Opticaly Emission Spectrometry, model Optima 2000 DV, Fa Perkin Elmer) pada panjang gelombang maksimum dimana perlakuan terhadap larutan baku standar dan blanko dikerjakan seperti pengerjaan terhadap sampel yang dianalisis. Hasil analisis larutan baku standar dibuat kurva kalibrasi dengan menggunakan persamaan regresi dan selanjutnya menjadi dasar untuk menetapkan konsentrasi logam $\mathrm{Fe}$.

\section{HASIL DAN PEMBAHASAN}

Parameter kualitas air laut merupakan faktor penting bagi kelangsungan hidup tumbuhan lamun.
Parameter kualitar air laut yang diukur meliputi kandungan oksigen terlarut (DO), konduktivitas, derajat keasaman $(\mathrm{pH})$, salinitas, suhu, dan turbiditas. Hasil pengukuran sifat fisikokimia perairan ekosistem padang lamun mengindikasikan kondisi perairan pada ekosistem padang lamun masih dapat dikategorikan pada golongan yang wajar (Tabel 1). Nilai rata parameter sifat fisikokimia yang diamati umumnya masih masuk pada rentang nilai yang diperolehkan sesuai baku mutu berdasarkan Kepmen Lingkungan Hidup Nomor 200 tahun 2004.

Nilai kandungan oksigen terlarut (DO) di setiap lokasi pengukuran relatif menurun tergantung assosiasi dan tingkat kepadatan lamun. Dari Tabel 1 menunjukkan bahwa konsentrasi DO tertinggi $(7,36 \mathrm{mg} / \mathrm{l})$ pada assosiasi mangrove dengan tingkat kepadatan tergolong 
Tabel 1. Data rata-rata nilai parameter sifat fisikokimia perairan di wilayah pesisir Kabupaten Donggala

\begin{tabular}{|c|c|c|c|c|c|c|c|}
\hline \multirow{2}{*}{ No. } & \multirow{2}{*}{ Kelompok } & \multicolumn{6}{|c|}{ Nilai rata-rata parameter fisikokimia perairan ") } \\
\hline & & DO (ppm) & Cond. $(\mu \mathrm{S} / \mathrm{cm})$ & $\mathrm{pH}$ & Sal. (\%o) & Suhu $\left({ }^{\circ} \mathrm{C}\right)$ & Turb. (NTU) \\
\hline 1. & L1S1 & 7,36 & 50,50 & 7,90 & 32,20 & 30,67 & 6,67 \\
\hline 2. & L1S2 & 7,27 & 50,20 & 8,07 & 32,27 & 31,07 & 7,00 \\
\hline 3. & L1S3 & 7,23 & 50,20 & 8,13 & 32,70 & 31,23 & 7,67 \\
\hline 4. & L2S1 & 7,31 & 50,30 & 8,00 & 32,23 & 31,17 & 7,00 \\
\hline 5. & L2S2 & 7,29 & 49,43 & 8,10 & 32,40 & 31,23 & 7,00 \\
\hline 6. & L2S3 & 7,09 & 49,27 & 8,17 & 33,00 & 31,27 & 7,33 \\
\hline 7. & L3S1 & 7,30 & 49,90 & 8,10 & 32,83 & 31,20 & 7,67 \\
\hline 8. & L3S2 & 7,04 & 49,30 & 8,13 & 32,90 & 31,27 & 8,00 \\
\hline 9. & L3S3 & 6,92 & 49,10 & 8,17 & 33,10 & 31,30 & 9,00 \\
\hline
\end{tabular}

${ }^{\top}$ Hasil pengukuran langsung di lapangan

sangat padat, dan terendah pada $(6,92 \mathrm{mg} / \mathrm{l})$ pada assosiasi terumbu karang dengan tingkat kepadatan tergolong tidak padat. Fruktuasi relatif DO di berbagai titik pengamatan diduga disebabkan pemakaian oksigen terlarut oleh tumbuhan lamun dan biota-biota yang hidup dalam ekosistem padang lamun. Pada tingkat kepadatan yang rendah pemakaian oksigen terlarut lebih besar disebabkan oleh pemakaian respirasi biota air dan bakteri nitrifikasi dalam proses siklus nitrogen di padang lamun daripada untuk keperluan respirasi akar dan rempang tumbuhan lamun akibatnya kandungan oksigen terlarut dalam air laut berkurang (Zulkifli, 2003).

Daya hantar listrik (konduktivitas) adalah kemampuan air untuk menghantar listrik. Nilai konduktivitas di setiap lokasi pengukuran relatif menurun tergantung assosiasi dan tingkat kepadatan lamun. Hasil pengukuran (Tabel 1) menunjukkan bahwa nilai konduktivitas tertinggi $(50,50 \mathrm{mS} / \mathrm{cm})$ pada assosiasi mangrove dengan tingkat kepadatan tergolong sangat padat, dan terendah $(49,1 \mathrm{mS} / \mathrm{cm})$ pada assosiasi terumbu karang dengan tingkat kepadatan tergolong tidak padat. Perbedaan relatif nilai konduktivitas perairan di wilayah kajian boleh jadi disebabkan oleh perbedaan kandungan garam terlarut. Hasil survey peneliti menunjukkan bahwa pada blok amatan I (Wilayah Kecamatan Sojol dan Dampelas), umumnya wilayah daratannya relatif lebih banyak aktivitas pertanian dan terdapat beberapa aliran sungai yang memungkinkan konsentrasi ion-ion terlarut yang terbawa oleh aliran sungai lebih besar dibandingkan dengan blok amatan II (Wilayah Kecamatan Balaesang, Kecamatan Sirenja, dan Sindue) dan blok amatan III (Wilayah Kecamatan Banawa, Kecamatan Banawa Tengah, Kecamatan dan Banawa Selatan).

Nilai derajat keasaman $(\mathrm{pH})$ di setiap lokasi pengukuran relatif naik tergantung assosiasi dan tingkat kepadatan lamun. Nilai tersebut menunjukkan bahwa $\mathrm{pH}$ perairan cenderung bersifat basa dan masih termasuk kisaran normal $\mathrm{pH}$ air laut di Indonesia yang pada umumnya bervariasi antara 6,0-8,5 (Tabel 1). Derajat keasaman $(\mathrm{pH})$ perairan sangat dipengaruhi oleh dekomposisi tanah dan dasar perairan serta keadaan lingkungan sekitarnya. Hasil pengukuran (Tabel 1) menunjukkan bahwa nilai pH tertinggi $(8,17)$ pada pada assosiasi terumbu karang dengan tingkat kepadatan tergolong tidak padat, dan terendah $(7,90)$ pada assosiasi mangrove dengan tingkat kepadatan tergolong sangat padat. Menurut Phillips dan Menes (1988), kisaran pH air laut adalah 7,8 - 8,2. Nilai keasaman $(\mathrm{pH})$ optimum untuk pertumbuhan lamun berkisar 7,3-9,0 (Phillips dalam Burrell \& Scubell, 1977).

Kisaran nilai salinitas di perairan padang lamun wilayah kajian di berbagai titik amatan berbeda-beda dan cenderung meningkat tergantung assosiasi dan tingkat kepadatan lamun. Nilai tersebut menunjukkan bahwa salinitas perairan pada asosiasi lamun dengan mangrove lebih tinggi dari asosiasi lainnya (Tabel 1). Hal ini diduga disebabkan oleh adanya pengaruh aliran massa air dari sungai yang umumnya ada di sekitar kawasan mangrove dan pola sirkulasi air yang berbeda di kawasan terumbu karang sehingga menyebabkan perbedaan salinitas di tiga asosiasi padang lamun tersebut. Umumnya salinitas di perairan pesisir selalu berfruktuasi karena dipengaruhi oleh berbagai faktor antara lain; pola sirkulasi air, penguapan, curah hujan, dan aliran sungai (Nybakken, 1988). Nilai-nilai salinitas di perairan padang lamun termasuk kisaran yang cocok untuk kehidupan lamun dan biota yang ada di dalamnya. Pertumbuhan lamun membutuhkan salinitas optimum berkisar 24 - 35\% (Hillman \& McComb dalam Hillman et al., 1989).

Hasil pengukuran salinitas (Tabel 1) menunjukkan bahwa salinitas tertinggi pada assosiasi dengan terumbu karang dengan tingkat kepadatan tergolong tidak padat $(33,1 \%)$, dan terendah pada assosiasi dengan mangrove dengan tingkat kepadatan tergolong sangat padat $(32,20 \%$ ). 
Parameter suhu merupakan salah satu faktor lingkungan yang dapat mempengaruhi pertumbuhan lamun. Berdasarkan hasil pengukuran (Tabel 1), suhu perairan terendah yaitu $30,67^{\circ} \mathrm{C}$ berada pada perairan lamun dengan status tingkat kepadatan tergolong sangat padat dan berasosiasi dengan mangrove sedangkan tertinggi yaitu $31,30^{\circ} \mathrm{C}$ pada padang lamun dengan status tingkat kepadatan tergolong tidak padat yang berasosiasi dengan terumbu karang. Dari nilainilai suhu tersebut menunjukkan bahwa suhu perairan di kawasan padang lamun relatif masih berkisar suhu optimal untuk pertumbuhan lamun yaitu $28-32^{\circ} \mathrm{C}$ (Zimmerman et al., 1987; Phillips \& Menez, 1988).

Kekeruhan atau turbiditas disebabkan oleh bahanbahan tersuspensi yang bervariasi dari ukuran koloidal sampai dispersi kasar tergantung dari derajat turbulensinya. Hasil pengukuran turbiditas perairan padang lamun wilayah kajian diberbagai titik amatan berbeda-beda dan cenderung meningkat tergantung assosiasi dan tingkat kepadatan lamun (Tabel 1). Berdasarkan hasil pengukuran turbiditas perairan terendah yaitu 6,67 NTU berada pada perairan lamun dengan status tingkat kepadatan tergolong sangat padat dan berasosiasi dengan mangrove sedangkan tertinggi yaitu 9,00 NTU pada padang lamun dengan status tingkat kepadatan tergolong tidak padat yang berasosiasi dengan terumbu karang. Perbedaan relatif nilai turbiditas wilayah kajian boleh jadi disebabkan oleh perbedaan partikel-partikel tersuspensi dan substrat dasar perairan, karena substrak yang halus cenderung mempunyai nilai turbiditas yang rendah.

Gambar 2 menunjukkan profil kandungan logam Fe dalam berbagai interaksi asosiasi dan status padang lamun. Analisis sidik ragam pengaruh konsentrasi Fe dalam padang lamun menunjukkan bahwa efek interaksi

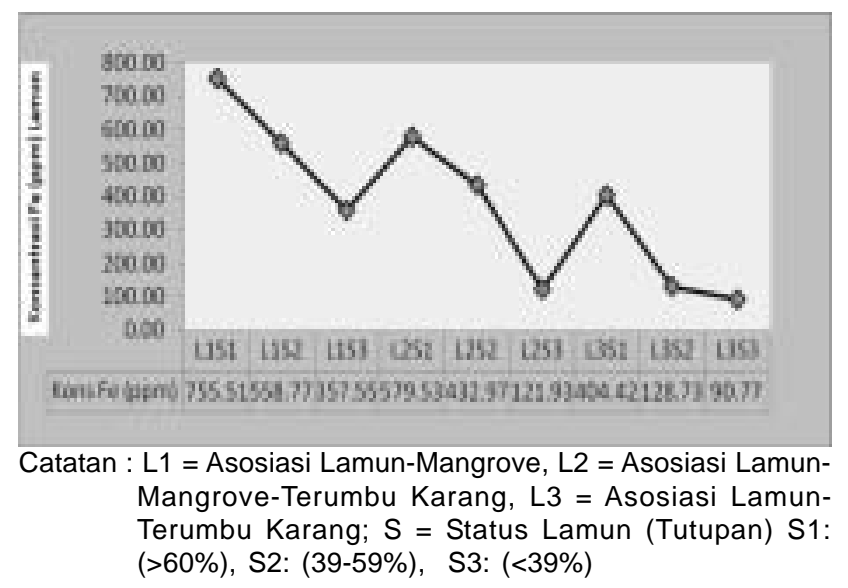

Gambar 2. Konsentrasi Fe dalam sistem ekologi lamun asosiasi dengan status padang lamun teruji nyata, ratarata konsentrasi $\mathrm{Fe}$ lamun tertinggi diperoleh pada status tingkat kepadatan tergolong sangat padat di daerah mangrove (L1S1) dengan rata-rata nilai $755,507 \mathrm{mg} / \mathrm{l}$, dan terendah dicapai pada interaksi pertumbuhan lamun pada status tingkat kepadatan tergolong tidak padat di daerah terumbu karang (L3S3) dengan rata-rata nilai $90,767 \mathrm{mg} / \mathrm{l}$. Gambaran hasil pengolahan data menunjukkan faktor status kepadatan padang lamun baik asosiasinya dengan mangrove, mangrove-terumbu karang, maupun terumbu karang dapat menjadi salah satu biondikator penting dalam menentukan kualitas lingkungan perairan laut. Berbagai hasil penelitian terdahulu menunjukkan bahwa tumbuhan lamun relatif dapat menjadi filter dalam stabilitas perairan karena mengandung senyawa makromolekul yang mempunyai kemampuan mengakumulasi logam dalam perairan. Tahril et al., (2008b), mengemukakan bahwa tumbuhan lamun mengandung protein dengan komposisi asam amino yang lengkap. Dalam merespon keberadaan unsur logam dalam ekosistem lamun, menurut Prange et al., (2000) ada tiga mekanisme penting respon unsur logam temasuk Fe terhadap tumbuhan lamun dalam lingkungan perairan, yaitu akumulasi (penyerapan), toksitas, dan kekurangan/ketiadaan. Penyerapan besi yang berlebihan akan menurunkan totalitas asam amino sehingga tumbuhan lamun menjadi stress (Prange et al., 2000), akan meningkatkan fotosensivitas terhadap akumulai besi dalam kloroflast (Kim \& Jung, 1993), terjadi pengurangan secara signifikan asparagin yang merupakan transfor nitrogen utama dalam penambahan chelat besi (Das et al., 1997; Prange et al., 2000).

Hubungan konsentrasi Fe dalam lamun terhadap parameter fisikokimia perairan berdasarkan analisis regresi dengan menggunakan langkah mundur (backward) antara konduktivitas, $\mathrm{DO}, \mathrm{pH}$, salinitas, suhu, dan turbiditas sebagai variabel bebas dan Felamun sebagai variabel tak bebas menunjukkan bahwa dari keenam parameter tersebut, hanya empat parameter yang berpengaruh langsung terhadap Felamun. Parameter yang berpengaruh langsung tersebut adalah DO, salinitas, suhu, dan turbiditas.

Analisis jalin hubungan antara komponen beberapa sifat fisikokimia, yaitu DO $\left(X_{1}\right)$, salinitas $\left(X_{2}\right)$, suhu $\left(X_{3}\right)$, dan kondukstivitas $\left(\mathrm{X}_{4}\right)$ dengan Fe-lamun $(Y)$ diharapkan mampu menggambarkan pengaruh langsung dan tidak langsung komponen fisikokimia terhadap Fe-lamun. 
Besarnya pengaruh komponen fisikokimia terhadap Felamun akibat assosiasi dan status padang lamun. Hasil analisis regresi menunjukkan bahwa DO $\left(X_{1}\right)$ dan turbiditas $\left(X_{4}\right)$ pengaruh positif terhadap peningkatan Fe-lamun, sedangkan salinitas $\left(X_{2}\right)$ dan suhu $\left(X_{3}\right)$ berpengaruh negatif terhadap Fe-lamun. Dari data pada Gambar 3 dan Tabel 2 menunjukkan bahwa faktor pembatas utama rendahnya Fe-lamun adalah tingginya salinitas, suhu, dan turbiditas perairan. Keberadaan logam Fe dalam ekosistem padang lamun di wilayah kajian relatif hanya disebabkan oleh faktor alamiah berupa aliran partikel dari daratan melalui sungai atau disebabkan oleh kondisi geologi perairan. Fakta menunjukkan bahwa aktivitas industri yang memungkin menghasilkan logam Fe ke perairan relatif tidak tersedia dan yang relatif ada hanyalah merupakan aktivitas pertanian di daratan. Hal ini menguatkan hubungan konsentrasi $\mathrm{Fe}$ dalam ekosistem lamun lebih didominasi oleh faktor suhu, salinitas, dan turbiditas (Tahril et al., 2008a).

Wilayah pesisir kabupaten Donggala umumnya mempunyai garis pantai yang terjal dan kedalaman perairan yang relatif berbeda memungkinkan terjadi perbedaan temperatur, salinitas, dan turbiditas perairan. Hasil pengukuran sifat fisikokimia perairan dalam penelitian ini menunjukkan perbedaan nilai salinitas, suhu, dan turbiditas pada berbagai status dan asosiasi padang lamun, disamping itu juga menggambarkan perbedaan konsentrasi Fe, sehingga konsentrasi Fe dalam ekosistem padang lamun diduga terdapat hubungan yang signifikan dengan nilai salinitas, suhu, dan turbiditas perairan. Grimm (1994) mengemukakan bahwa fluktuasi temperatur perairan dipengaruhi oleh absorbsi sinar matahari, kecepatan arus, kedalaman air dan kemiringan tempat, akibatnya distribusi konsentrasi logam-logam juga mengalami perubahan. Perubahan suhu akan mempengaruhi distribusi, metabolisme, nafsu makan, reproduksi organisme perairan serta berpengaruh langsung terhadap proses fotosintesis fitoplankton dan tanaman. Juga Azkab dan Kuswara (1992) dan Bengen (2001), menyatakan bahwa parameter lingkungan antara lain ; kecerahan, suhu, salinitas, substrat dan kecepatan arus dapat mempengaruhi distribusi dan pertumbuhan ekosistem padang lamun.

\section{KESIMPULAN}

Hasil penelitian menunjukkan kualitas sifat fisikokimia perairan di wilayah perairan pantai Kabupaten Donggala relatif masih sangat baik. Parameter DO dan turbiditas berpengaruh positif terhadap peningkatan $\mathrm{Fe}$-lamun di berbagai asosiasinya. Faktor pembatas utama rendahnya Fe-
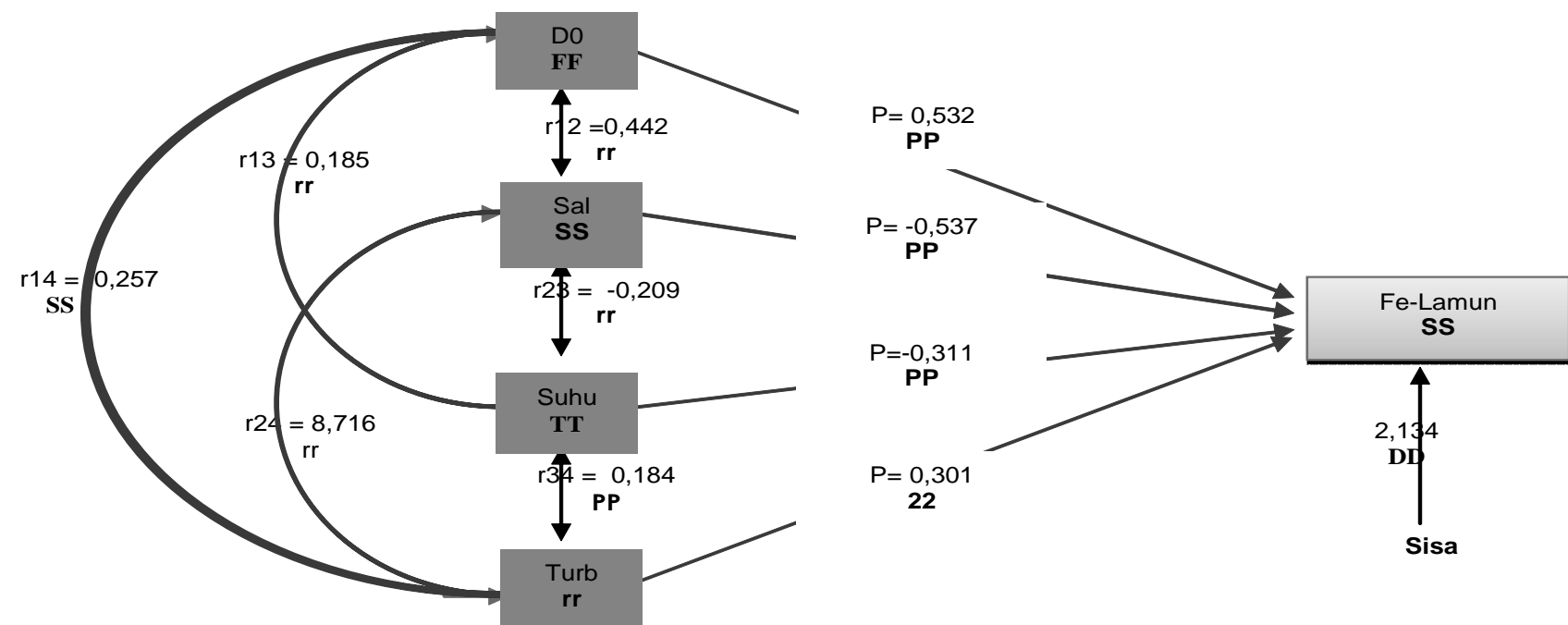

Gambar 3. Diagram jalin hubungan antara variabel hasil analisis fisikokimia Seperti $D O\left(X_{1}\right)$, salinitas $\left(X_{2}\right)$, suhu $\left(X_{3}\right)$, dan turbiditas $\left(\mathrm{X}_{4}\right)$ dengan Fe-Lamun $(\mathrm{Y})$ pada setiap kombinasi perlakuan

Tabel 2. Analisis pengaruh komponen fisikokimia pada Fe lamun

\begin{tabular}{|c|c|c|c|c|c|c|}
\hline \multirow{2}{*}{$\begin{array}{c}\text { Variabel Bebas } \\
\text { (Komponen Hasil) }\end{array}$} & \multirow{2}{*}{$\begin{array}{l}\text { Pengaruh } \\
\text { Langsung }\end{array}$} & \multicolumn{4}{|c|}{ Pengaruh tidak langsung melalui variabel } & \multirow{2}{*}{$\begin{array}{c}\text { Pengaruh } \\
\text { Total }\end{array}$} \\
\hline & & $\mathrm{X} 1$ & $\mathrm{X} 2$ & X3 & $\mathrm{X} 4$ & \\
\hline $\mathrm{DO}(\mathrm{X} 1)$ & 0,532 & - & 0,442 & 0,185 & $-0,257$ & 0,902 \\
\hline $\mathrm{SAL}(\mathrm{X} 2)$ & $-0,537$ & $-0,438$ & - & $-0,209$ & 8,716 & 7,531 \\
\hline SUHU (X3) & $-0,311$ & $-0,316$ & $-0,362$ & - & 0,184 & $-0,805$ \\
\hline TURB (X4) & 0,301 & $-0,456$ & $-0,448$ & $-0,191$ & - & $-0,794$ \\
\hline
\end{tabular}


lamun adalah tingginya salinitas dan suhu perairan. Hasil di atas, jika digabungkan bersama hasil analisis mineral makro dan mikro lainnya dapat menjadi dasar untuk memperkirakan status kesuburan lamun.

\section{UCAPAN TERIMA KASIH}

Penulis mengucapkan terima kasih kepada Rektor Universitas Hasanuddin dan Direktur Pascasarjana Universitas Hasanuddin atas kesediaannya memberikan kesempatan untuk mengikuti program Doktor (S3) di Universitas Hasanuddin. Ucapan terima kasih juga disampaikan kepada Kepala STORMA atas kesediannya menerima penulis untuk analisis sampel mengunakan ICP-OES, Dr. Ir. Saipul Darman, M.S atas bantuannya dalam analisis data, dan Asmuin, S.Sos., Herman, serta mahasiswa program studi kimia PMIPA FKIP Universitas Tadulako atas bantuannya dalam survey dan pengambilan sampel di lapangan.

\section{DAFTAR PUSTAKA}

Azkab. \& Kiswara, W. 1992. Status dan Khasanah Pengetahuan Ekosistem Lamun di Indonesia, Puslitbang Oseanogtrafi-LIPI, Jakarta.

Bengen, D.G. 2001. Sinopsis Ekosistem dan Sumberdaya Alam Pesisir.

Burrell, D.C. \& Schubel, J.R. 1977. Seagrass ecosystem oceanography. dalam: McRoy, $P$ and Mc Millan, C. (eds). Seagrass Ecosystem: a Scientific Perspective. New York: Marcel Dekker.

Das, P., Samantaray, S. \& Rout, G.R. 1997. Studies of cadmium in plants: a review. Environmental Pollution 98: 29-36.

Erftemeijer, P.L.A. 1992. Factor Limiting Growth and Production of Tropical Seagrasses: Nutrient Dynamic in Indonesian Seagrass Beds (Buginesia IV). Tentative Final Report Prepared For LIPI And WOTRO, Ujung Pandang.

Grimm, MB. 1994. Disturbance, Succession, and Ecosystem Processed in Streams: A Case Study form the Desert. Dalam P. S. Giller, A. G. Aquatic Ecology: Scale, Pattern and Process. Blackwall Science. London.

Hasnah, P. 1994. Studi Logam Fe dan Mangan Dalam Lamun Dengan SSA, Skripsi Fakultas Matematika dan IImu Pengetahuan Alam Universitas Hasanuddin, Makassar.

Hillman, K., Walker, D.J., Larkum, A.W.D. \& Mc Comb, A.J. 1989. Productivity and Nutrient Limitation of Seagrasses.
Biology of Seagrasses. Netherland: Elsevier Science Publishers.

Keputusan Menteri Negara Lingkungan Hidup Nomor : 200 Tahun. 2004. Tentang Kriteria Baku Kerusakan dan Pedoman Penentuan Status Padang Lamun. (Online), Diakses Tanggal 27 Pebruari 2007.

Lakitan, B. 2007. Dasar-dasar Fisiologi Tumbuhan. PT. RajaGrafindo Persada. Jakarta.

Nybakken, J.W. 1988. Biologi Laut Suatu Pendekatan Ekologis (Terjemahan). Gramedia, Jakarta.

Nur Aini. 1994, Distribusi Logam Cu, Zn, Pb, dan Cd pada Lamun, Skripsi (tidak dipublikasikan) Fakultas Matematika dan IImu Pengetahuan Alam Universitas Hasanuddin, Makassar.

Patriquin, D.G. 1992. The Origin of Nitrogen and Phosphorus for Growth of The Marine Angiosperm Thalassia Testudinium. Mar. Biol 15: 35-46.

Persulessy, A.E., Pramudji. \& Manik, J.M. 1998, Nutrien Air Poros Dalam Sedimen Berkarbonat dan Silikat di Padang Lamun Kotania (Seram Barat) Dalam Prosiding Seminar Kelautan LIPI-UNHAS Ke 1. Balitbang Sumberdaya Laut Puslitbang Oseanologi - LIPI Ambon.

Philips, C.R. \& Menez, E.G. 1988. Seagrass. Smith Sonian. Institutions Press. Washington D.C.

Prange, J.A. \& Dennison, W.C. 2000. Physiological Responses of Five Seagrass Species to Trace Metals. Marine Pollution Bulletin 41: Nos. $7 \pm 12$, Pp. $327 \pm 336$

Saleh, M. 2003. Analisis Konsentrasi Fosfat pada Akar, Batang dan Daun (Enhalus acoroides dan Thalassia hemprichii) pada Daerah Puntondo Kabupaten Takalar. Skripsi Fakultas Matematika dan IImu Pengetahuan Alam Universitas Hasanuddin, Makassar.

Silva, J. \& Santos, R. 2003. Daily Variation Patterns in Seagrass Photosynthesis Along a Vertical Gradient S. Marine Ecology Progress Series 257: 37-44.

Tahril, Taba P., La Nafie, N. \& Noor, A. 2008a. Status dan Kelimpahan Lamun (Seagrass) sebagai Sumber Nutrisi Perairan di Wilayah Pesisir Kabupaten Donggala. Jurnal Kabelota 1(3): 1-9.

Tahril et al. 2008b. Peta Protein Berbagai Spesies Lamun di Pantai Kabupaten Donggala Sulawesi Tengah. Jurnal Torani 4(18): 349-353.

Taiz, L. \& Zeiger, E. 2002. Plant Physiology. Sinauer Associates, Inc. Publisher Sunderland, Massachusetts

Yamamuro, M., Kayanne, H. \& Yamano, H. 2003. ä15 N of seagrass leaves for monitoring anthropogenic nutrient increases in coral reef ecosystems. Marine Pollution Bulletin 46: 452-458.

Zimmerman, R.C., Smith, R.D. \& Alberte, R.S. 1987. Is growth of the Eelgrass nitrogen limited? A numerical simulation of effect of light and nitrogen on the growth dynamics of Zostera marina. Marine Ecology Progress Series, 41: 167176.

Zulkifli, E. 2003. Kandungan Zat Hara dalam Air Poros dan Air Permukaan Padang lamun Bintan Timur. Jurnal Natur Indonesia 5(2):139-144. 